\title{
THE DYNAMICS OF FERROALLOYS COMMODITY FLOWS WITHIN RUSSIA
}

\author{
G. Yu. Boyarko' ${ }^{1}$, V. Yu. Khatkov², L. M. Bolsunovskaya ${ }^{1}$ \\ ${ }^{1}$ National Research Tomsk Polytechnic University (Tomsk, Russia) \\ ${ }^{2}$ Gazprom PJSC (St. Petersburg, Russia)
}

\section{E-mail:gub@tpu.ru; bolsunovskl@tpu.ru}

\section{AUTHOR'S INFO \\ G. Yu. Boyarko, Dr. Econ. Cand. Geol., Prof. \\ V. Yu. Khatkov, \\ Head of Dept. 817 \\ L. M. Bolsunovskaya, \\ Cand. Phil., Associate \\ Prof.}

Key words:

ferroalloys, Russia, production, import, export, consumption, import substitution.

\author{
A B S T RAC T
}

The paper deals with the commodity flows (production, import, export, consumption, prices) of manganese, chromium, silicon, vanadium, niobium, molybdenum, tungsten, titanium and nickel ferroalloys in dynamics from 2000 to 2019 throughout Russia. The paper also specifies groups of ferroalloys: import-dependent (silicomanganese, metallic manganese, ferroniobium), export-oriented (ferrosilicon, ferrochrome, ferrovanadium, ferromolybdenum) and counter import-export (ferromanganese) flows. The paper notes that there has been a liquidation of import dependence on ferromanganese and ferromolybdenum. Trends in shares of Russian ferroalloys in their world production and consumption, as well as in the world trade are determined. The share of Russia in the world production of ferromolybdenum increased (up to 5-8 \%), while ferrovanadium and ferrosilicon decreased. The shares of Russian consumption (in world demand volume) of ferrovanadium (up to 11-7 \%) and ferroniobium (up to 5-7\%) increased, and the shares of national demand for ferrosilicon and silicomanganese in the volume of world supply decreased. The shares of Russian import in the world trade volume of metallic manganese (up to 11-16\%) and ferroniobium (up to $5 \%$ ) are increased, and the share of national imports of silicomanganese and ferromanganese decreased. The shares of Russian export in the world trade volume of ferrosilicon (up to 17-21\%) and ferromolybdenum (up to 5-8 \%) are increased, while the share of national exports of ferrovanadium decreased. As a result, the authors give proposals to mitigate the import dependence on certain types of ferroalloys (metallic manganese, silicomanganese and ferroniobium.

\section{Introduction}

Ferroalloys are large-scale products of alloying addition for iron and steel industry, their total consumption is $25-30 \mathrm{~kg}$ per 1 ton of steel [1-4]. Their production and consumption constitute hundreds of thousands of tons per year and requires the continuity of commodity supplies; therefore, most types of raw materials for their production are included in the list of strategic mineral resources. If under the Soviet Union planned economy the integration of sources of raw materials and ferroalloy plants was self-sufficient, then under the market economy and territorial division of the national industries of the CIS (Commonwealth of Independent States), the commodity flows of ferroalloy raw materials and the ferroalloys themselves have significantly transformed, which in some cases have become import-dependent products [5-7]. Additionally, ferroalloys are only intermediate commodity products used in the production of steel and non-ferrous alloys and their demand is dynamically dependent on the end product volume. The lack of domestic ferroalloys production (silicomanganese, metal manganese, ferroniobium) is met by import, and the excess production volumes (ferrosilicon, ferrochromium, ferrovanadium, ferromolybdenum) are exported.

\section{Research Methods}

The aim of this paper is to study the turnover of ferroalloy products in order to make proposals for optimizing their flows. The information sources: State reports of the Federal Agency for Subsoil Use [8], statistical data of the State Statistics Service of Russia [9], the Russian Federation Customs Service [10] and the UN World Statistics Department [11], Reviews of information centers $[12,13]$. For some commodity products, there are reliable data gaps, in these cases, estimates were made of their parameters, and if it was impossible - the periods for analyzing commodity flows were reduced.

\section{State of the Russian ferroalloy market}

Up to 4 million tons of ferroalloys are produced in Russia annually. Enterprises producing ferroalloy products are shown in table $\mathbf{1}$, and their location is shown in Fig. 1. Their location based on proximity to raw material sources (deposits), or to consumers - metallurgical plants.

The volumes and directions of ferroalloys trade varied with regard to time as a result of changes in their prices, and especially during the global financial crisis of 2008 and after the economic sanctions of 2014.

Manganese ferroalloys. On the territory of Russia, there are no developed fields of high-quality manganese ores within the existing transport infrastructure. Therefore, the production of ferromanganese and silicomanganese was carried out using imported raw materials by Russian ferroalloy plants - Chelyabinsk IEMP PJSC, Kosogorsky MP PJSC, Satka ISP and Klyuchevsky FAP JSC. Moreover, the shortage of manganese ferroalloys was covered by imports.

Ferromanganese production in Russia tends to grow from $95 \mathrm{Kt}$ (37\% of national consumption) in 2000 to $280 \mathrm{Kt}$ in 2018 (exceeding Russian consumption by $18 \%$ ), see fig. 2 , FeMn national consumption of ferromanganese is variable: 


\begin{tabular}{|c|c|c|}
\hline Enterprise & Location & Production \\
\hline $\begin{array}{l}\text { Chelyabinsk integrated electrometallurgical } \\
\text { plant PJSC }\end{array}$ & Chelyabinsk & $\begin{array}{l}\text { ferromanganese, silicomanganese, ferrochrome, } \\
\text { ferrosilicon, silicocalcium }\end{array}$ \\
\hline Kosogorsky metallurgical plant PJSC & Tula & ferromanganese \\
\hline Satka iron smelting plant JSC & Satka, Chelyabinsk Region & ferromanganese, silicomanganese \\
\hline Klyuchevsky ferroalloy plant JSC & Dvurechensk, Sverdlovsk Region & $\begin{array}{l}\text { ferromanganese, ferrochrome, metallic chromium, } \\
\text { ferrosilicon, ferrotitanium, ferromolybdenum, ferrotungsten, } \\
\text { ferroniobium, ferroboron, zirconium ferrosilicon }\end{array}$ \\
\hline Serov ferroalloy plant JSC & Serov, Sverdlovsk Region & ferrochrome, ferrosilicon \\
\hline Tikhvin ferroalloy plant LLC & Tikhvin, Leningrad Region & ferrochrome \\
\hline Novotroitsk plant of chrome compounds JSC & Novotroitsk, Orenburg Region & ferrochrome, metallic chromium \\
\hline Serovskiy plant of small metallurgy LLC & Serov, Sverdlovsk Region & ferrochrome, ferronickel \\
\hline Kuznetsk ferroalloys JSC & Novokuznetsk, Kemerovo Region & ferrosilicon \\
\hline Bratsk ferroalloy plant JSC & Bratsk, Irkutsk Region & ferrosilicon, industrial silicon \\
\hline Kremniy JSC & Shelikhov, Irkutsk Region & industrial silicon \\
\hline RUSAL Kremniy - Ural LLC & Kamensk-Uralskiy, Sverdlovsk Region & industrial silicon \\
\hline EVRAZ vanadium Tula JSC & Tula & ferrovanadium \\
\hline Sorsky ferromolybdenum plant LLC & Sorsk, Republic of Khakassia & ferromolybdenum \\
\hline Zhirekenskiy ferromolybdenum plant LLC & Zhireken, Trans-Baikal Territory & ferromolybdenum \\
\hline Nizhnevolzhskiy ferroalloy plant LLC & Kamyshin, Volgograd Region & ferromolybdenum \\
\hline Ryazan plant of ferroalloys \& ligatures LLC & Ryazan & ferromolybdenum, ferrotungsten, ferrovanadium \\
\hline Moliren LLC & Roshal, Moscow Region & ferromolybdenum, ferrotungsten, ferroniobium \\
\hline Polema JSC & Tula & ferromolybdenum, tungsten metal \\
\hline Unech plant of refractory metals LLC & Unecha, Bryansk Region & ferrotungsten \\
\hline VSMPO-AVISMA PJSC & Verkhnyaya Salda, Sverdlovsk Region & ferrotitanium \\
\hline Solikamsk magnesium plant PJSC & Solikamsk, Perm Territory & ferrotitanium, ferroniobium \\
\hline Kanta LLC & Chelyabinsk & ferrotitanium \\
\hline Nova Met LLC & Chelyabinsk & ferrotitanium \\
\hline Kaskad Titan JSC & Kostroma & ferrotitanium \\
\hline Zubtsovsky metallurgical plant LLC & Zubtsov, Tver Region & ferrotitanium, ferrotungsten \\
\hline South Ural nickel plant PJSC & Orsk, Orenburg Region & ferronickel \\
\hline Svetlinsky ferronickel plant LLC & Svetlyi, Orenburg Region & ferronickel \\
\hline Special ferroalloys LLC & Ulyanovsk & ferronickel \\
\hline Tuim non-ferrous metal processing plant & Tuim, Republic of Khakassia & nanganese \\
\hline
\end{tabular}

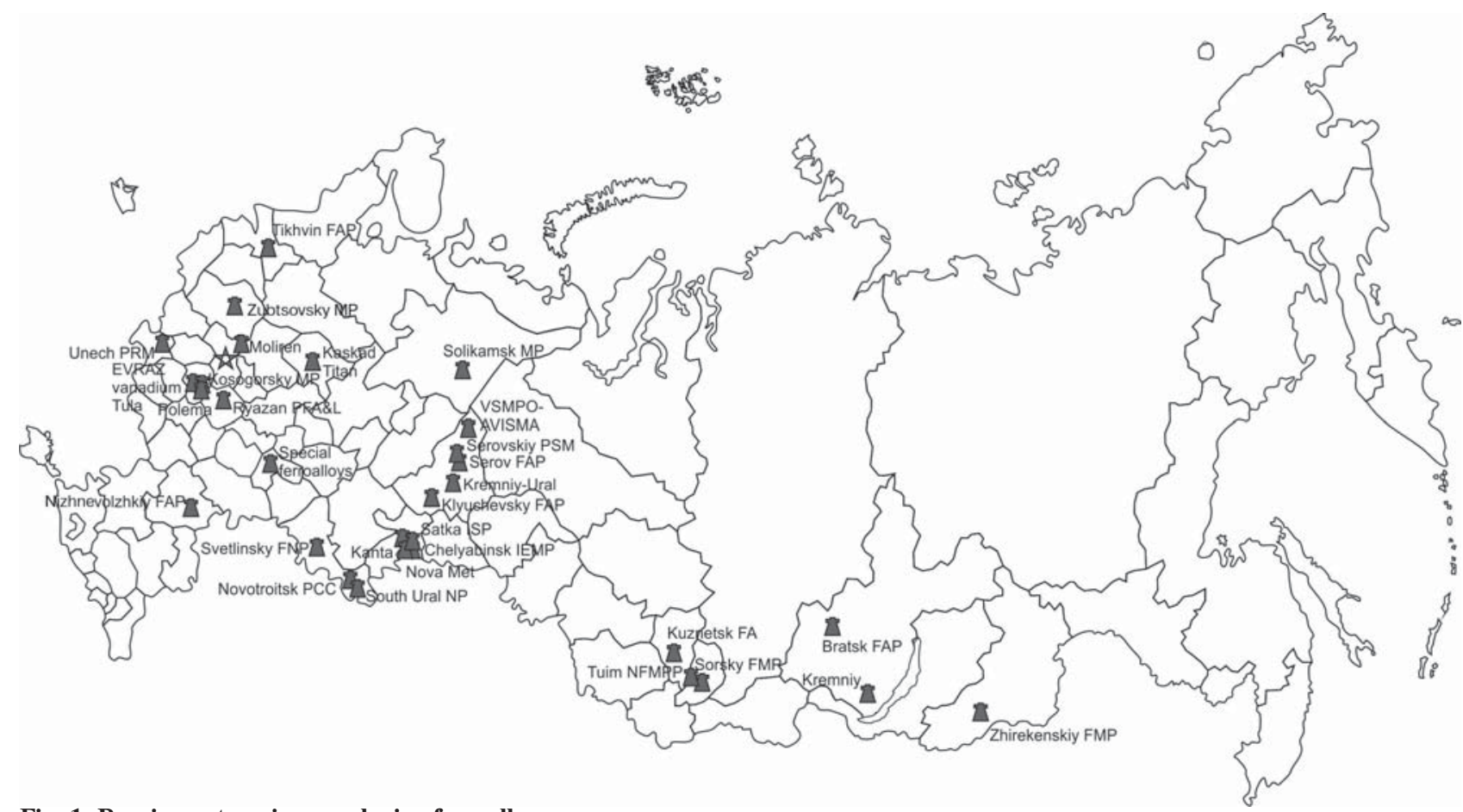

Fig. 1. Russian enterprises producing ferroalloys 

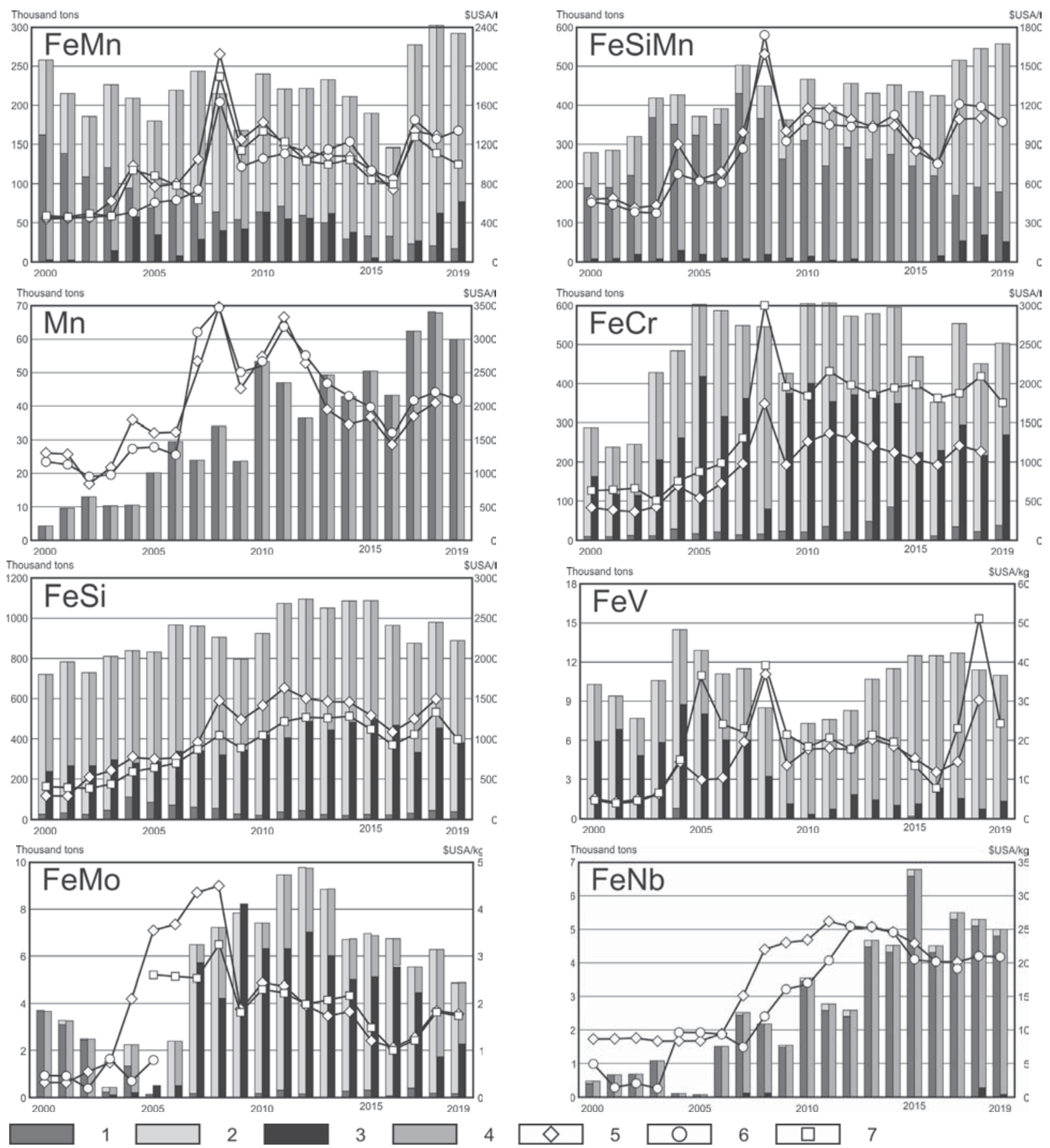

Fig. 2. Shifts in balances of ferroalloys commodity flows in Russia and their prices for 2000-2019:

1 - import, 2 - production, 3 - export, 4 - net consumption, 5-7-prices (5- average for world exports,

6 - imports to Russia, 7 - exports from Russia)

in the period from 2000 to $2004-210-250 \mathrm{Kt} / \mathrm{year}$, and in 2005-2016 it decreased to 145-185 Kt/year with a crisis minimum of $125 \mathrm{Kt}$ in 2009 and increased again to 210-250 Kt/year in 2017-2019.

Previously, the deficit in ferromanganese consumption overlapped with imports from Ukraine and Norway, but in recent years, supplies from these countries are being replaced by imports from Georgia and Kazakhstan (see fig. 3, FeMn). At the same time, the volume of ferromanganese imports significantly decreased from $160 \mathrm{Kt}$ in 2000 to $18 \mathrm{Kt}$ in 2019 (-3.9\% / year).
Therefore, ferromanganese in 2014 left full import dependence for an import-independent category (see Fig.4a), and even its export flow appeared (up to $78 \mathrm{Kt}$ / year), and according to the balance of counter importexport trade net export of ferromanganese has been observed since 2018 [14]. Export volumes and the number of importing countries are variable over time (see fig. 5, FeMn).

The national production of silicomanganese increased from 90 in 2000 to $377 \mathrm{Kt}$ in 2019 (+6.5\% / year), as well as consumption during this period from 270 to $505 \mathrm{Kt} /$ year 
Thousand tons

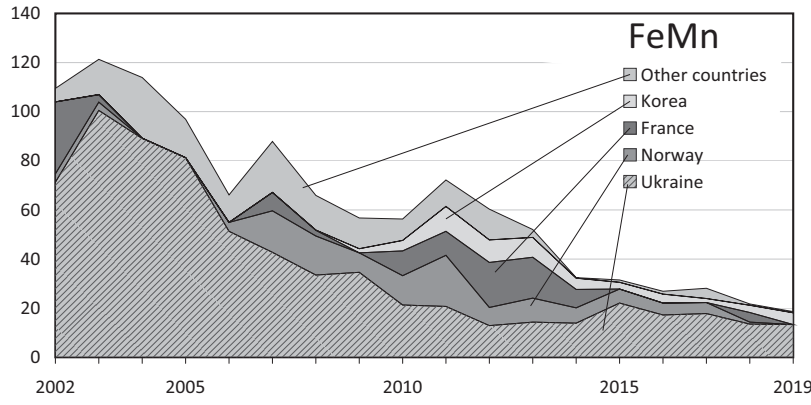

Thousand tons

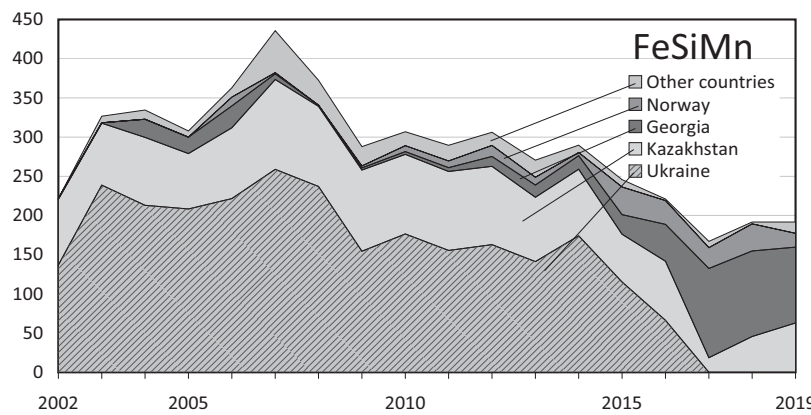

Thousand tons

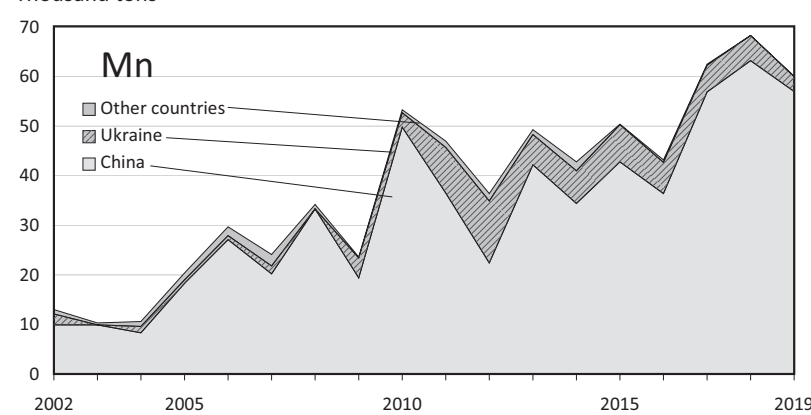

Thousand tons
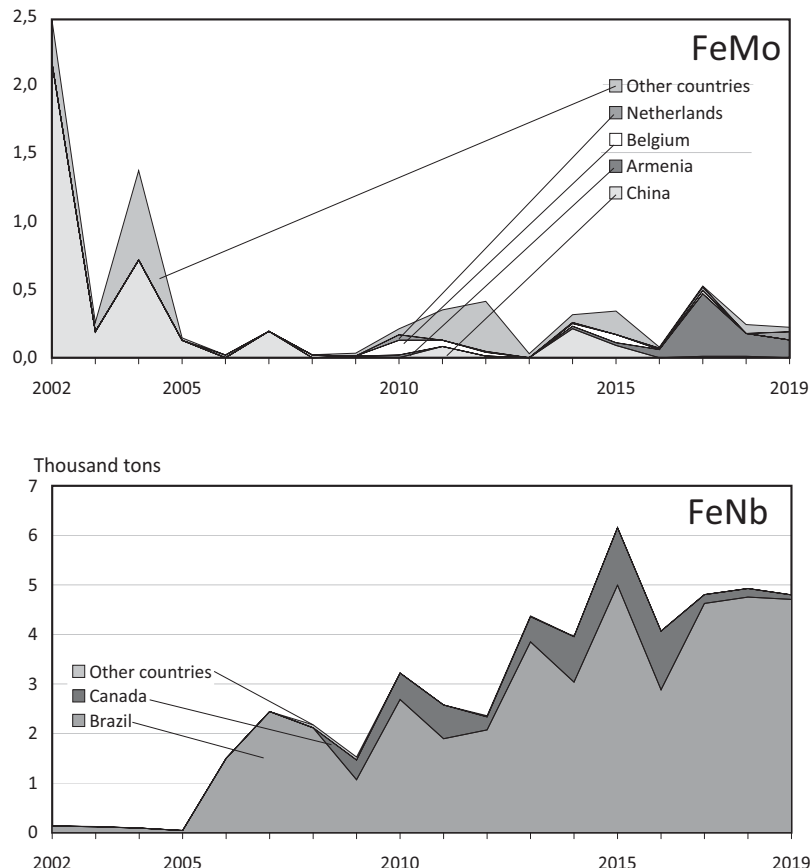

Fig. 3. Behaviour of import commodity flows of ferroalloys supplied to Russia by source countries for 2002-2019

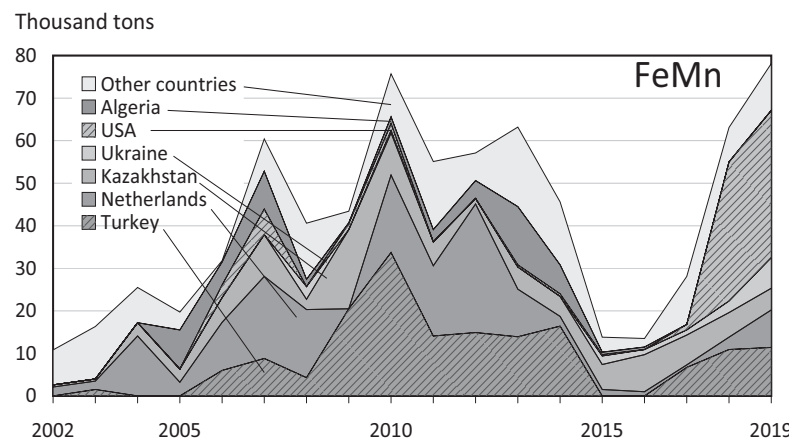

Thousand tons
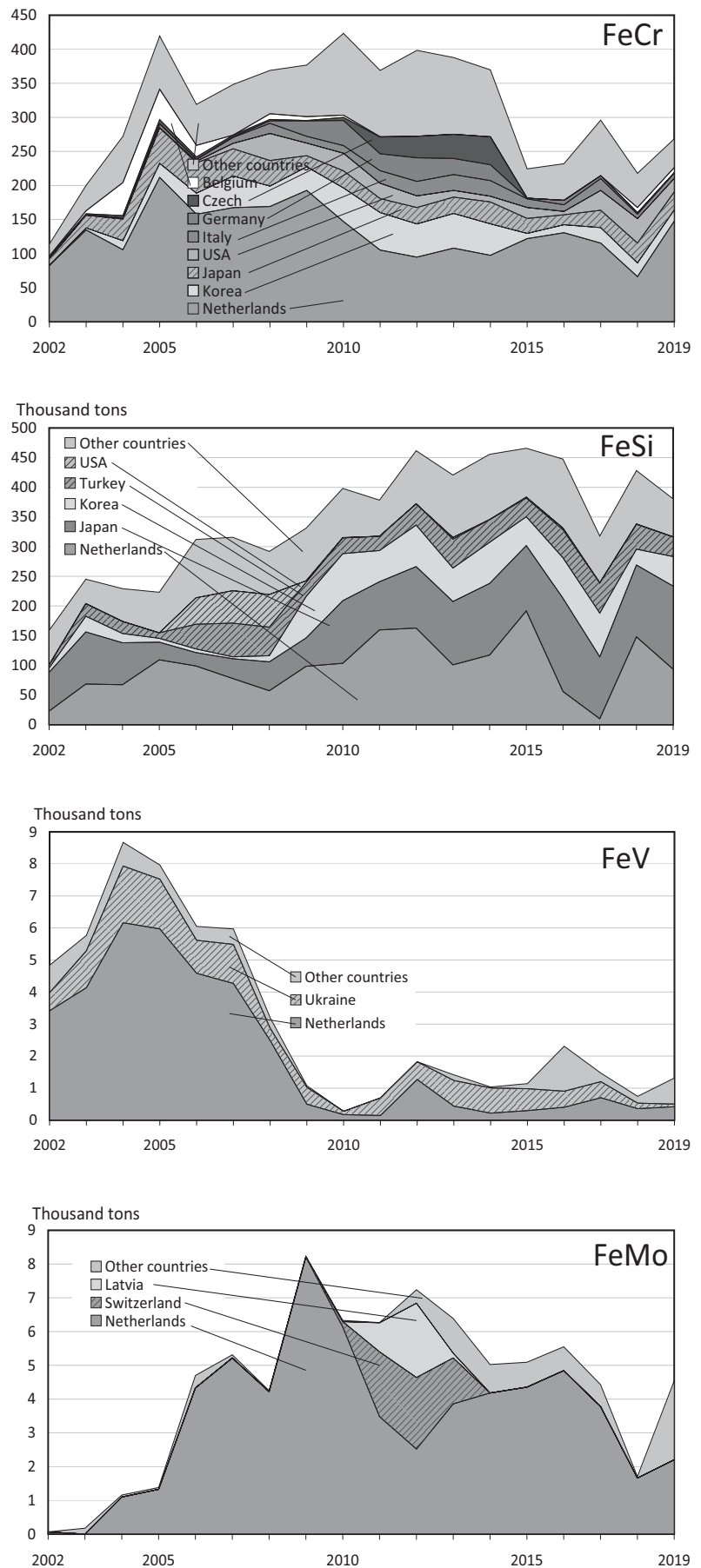

Fig. 4. Behaviour of export commodity flows of ferroalloys supplied from Russia by buyer countries for 2002-2019 

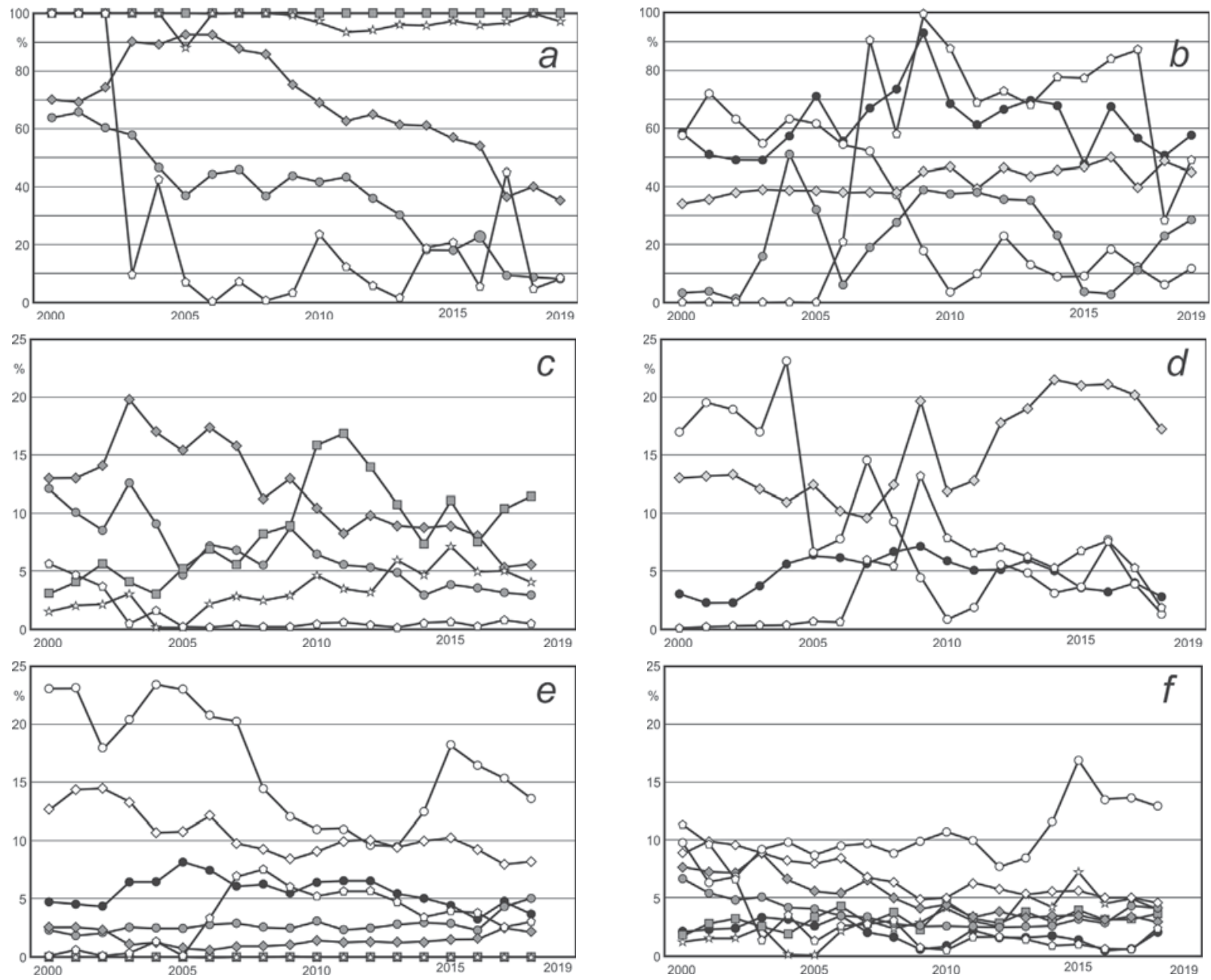

Fig. 5. Shifts of commodity flows of Russian ferroalloys in national and world production and consumption, in world imports and exports for 2000-2019:

$a$-Russian imports in national consumption, $b$ - Russian exports in national production, $c$ - Russian imports in world trade, $d$-Russian exports in world trade, $e$ - Russian production from world production, $f$-Russian consumption from world production;

$\diamond$-ferromanganese, $\diamond$-silicomanganese, $\square$-metallic manganese, $\bullet$-ferrochrome, $\bigcirc$-ferrovanadium, $\diamond$-ferrosilicon, ๑ - ferromolybdenum, - it - ferroniobium

$(+5.3 \% /$ year), see fig. 2, FeSiMn. Nevertheless, imports of silicomanganese remained at the same high level: in 2000 2002 they constituted 170-190 Kt/year (69-74 \% of consumption), and in 2003-2008 - 310-435 Kt/year (85-92\%), and as of 2008, the volume of its imports began to decrease to $170-192 \mathrm{Kt} /$ year (rates of drawdown $-7.2 \% /$ year). Supplies from Georgia, Kazakhstan and Norway (see fig. 3, FeSiMn) replaced the reduced imports from Ukraine. However, silicomanganese is still an import-dependent commodity (37\% of consumption in 2019, see fig. 5a).

A new commercial product - metallic manganese is in demand, and its consumption, increased from 4.3 Kt in 2000 to $68 \mathrm{Kt}$ in 2018 (+12.2\%/year), see fig. 2, $\mathrm{Mn}$. There is no production of this product in Russia. At present, the need for it is covered by imports from China (76-95 \%) and Ukraine (5-17 \%). Moreover, the share of imports of this product by Russia in the volume of world trade increases over time from $1.5 \%$ in 2000 to $7.1 \%$ in 2015 (see fig. 5c).
International commodity prices for all manganese products is similar: price advance in 2000-2008 with a local maximum in 2004, a slight decline in 2006-2007 and an absolute maximum in 2008 (maximum of the overheated steel market); the trend in price decline as a result of the economic crisis recession in 2009-2016, the resumption of price increases in 2017 and the stabilization of price levels in 2018-2019. (see Fig. 2,FeMn,FeSiMn). The asynchronous price surge for metallic manganese in 2010-2011 was extremely anomalous. (see Fig. 2,Mn).

Russian import ferromanganese prices for the period from 2000 to 2012, which were less than world by $6-29 \%$, and since 2013. - already 7-15\% higher. The behavior of silicomanganese price is similar to deviations in the first period by $4-15 \%$ lower, in the second by $5-11 \%$ higher. The period of low manganese metal import prices was ended in 2006 (10-20\% lower than world prices), and later imports were $4-13 \%$ more expensive than world prices, with the exception of an abnormal surge in prices for this product in 2010-2011. 
The current decrease in the commodity of manganese ore import from Ukraine requires its replacement. This is possible through the development of new manganese deposits [8], involvement in the processing of technogenic waste of ferroalloy production [15], changes in the structure of ferroalloy consumption in metallurgy [16], involvement in the production of new types of manganese raw materials [17-19]. Even the introduction of the South Khingan (Jewish Autonomous Region) and Porozhinsky (Krasnoyarsk Territory) deposits [8] will not completely solve the problem of supplying high-quality manganese ores. The exploration project of the largest in Russia Usinsk deposit of carbonate manganese ores (Kemerovo Region) is generally focused on the narrow production of metallic manganese [20]. The most effective policy therefore will be to develop economic ties within the SCO (Shanghai Cooperation Organisation) and BRICS supported by stable flows of manganese ores and ferroalloys from Kazakhstan, South Africa and Brazil.

Chromium ferroalloys. For a long time no geological exploration of chrome raw materials was carried out on the territory of Russia, and only in the 90ies of the XX century, they were resumed. In 2004, the national production of chromite was resuming (the Central deposits in Yamal-Nenets Autonomous Area and Glavnoe Saranovskoe in Sverdlovsk Region), which reached $790 \mathrm{Kt}$ in 2005 and provides up to $40 \%$ of the required consumption of ferroalloy plants.

Ferrochrome flows record in Russia is shown in fig. 2, $\mathrm{FeCr}$. Ferrochromium is produced at Serov FAP JSC, Chelyabinsk IEMP PJSC, Klyuchevsky FAP JSC, Tikhvin FAP LLC, Novotroitsk PCC JSC and Serovskiy PSM LLC. Due to the high world ferrochromium prices, Russian ferroalloy plants are not limited to providing only national metallurgy, for which there is sufficient volume of their own raw materials. Using strong economic ties with suppliers (Donskoy GOK in the Republic of Kazakhstan) and short transport patterns for the supply of raw materials, Russian ferroalloy plants produce ferrochromium more than 2-2.5 times the country's national needs.

Ferrochrome production in Russia between 2000 and 2002 was at the level of 220-280 Kt per year. After a significant increase in the national chromite production and an increase in world ferrochromium prices, its production increased to a maximum of $584 \mathrm{Kt}$ in 2005 , remaining at the level of 520-580 Kt/year until 2008. The 2009 crisis led to a local production minimum of $400 \mathrm{Kt}$ in 2009, but later, within falling world ferrochromium prices, its production began to decline, up to $340 \mathrm{Kt}$ in 2016, but in 2017-2019 the production level increased to $427-517 \mathrm{Kt} / \mathrm{year}$.

Most part of the ferrochromium produced is exported - from 116 to $416 \mathrm{Kt} / \mathrm{year}$, which is 48 to $74 \%$ of production (see fig. $5 b$ ). Small volumes of ferrochromium imports represent cross-border local trade flows at a maximum of $37 \mathrm{Kt} /$ year. The national net consumption of ferrochrome is at the level of 150-260 Kt/year.

The behaviour of international ferrochromium prices completely repeat the trends in prices for manganese ferroalloys with an absolute maximum in 2008 and local min- imums in 2005, 2009 and 2016 (see fig. 2, FeCr). Due to the prevalence of more expensive varieties of ferrochrome in its export, Russian export prices are consistently higher than world ones: in the period of 2000-2010 - by 50-80\% (in the crisis year of 2009, having decreased to $+3 \%$ ), and starting from 2011 - by $18-45 \%$ (again, in the crisis of sanctions, a decrease to $+8 \%$ in 2015).

The situation with the import dependence of Russian ferroalloy plants on chromium raw materials is not tense in view of sustainable economic linkages of Russia with Kazakhstan and the emergence of a new import flow from South Africa. Besides, the own chromite mineral resources base is sufficient and the production capacity for their extraction is only increasing. The favorable conjuncture of high world prices makes it possible to produce an excess amount of ferrochromium for national consumption (50-70\% of production), directing this flow of goods for export. It is proposed, as for manganese products, to involve in the processing of industrial wastes of ferrochrome production [15], as well as changes in the consumption pattern of ferroalloys in metallurgy in order to reduce their specific consumption [16]. Small volumes of metal chromium are produced at the Klyuchevskoy FAP and Novotroitskiy PCC - at the level of 15-17 Kt per year, and most of it is exported (up to $17 \mathrm{Kt} /$ year).

Silicon ferroalloys. Ferrosilicon flow dynamics in Russia is shown in fig. 2, FeSi. The raw material base of silica in Russia is practically unlimited, the volume of industrial production is determined by the availability of demand and free energy capacities, as the synthesis of ferrosilicon and industrial silicon is energy intensive. Ferrosilicon is produced at Kuznetsk FAP JSC, Chelyabinsk IEMP PJSC, Serovskiy PSM LLC, Klyuchevsky FAP JSC and Bratsk FAP JSC.

Ferrosilicon production in Russia between 2000 and 2005 was at the level of 690-750 Kt/year (see fig. 2, FeSi). After the expansion of energy-intensive production facilities using natural gas energy [21], the production of ferrosilicon increased to $900-1000 \mathrm{Kt} / \mathrm{year}$. Small volumes of the import of ferrosilicon $(25-45 \mathrm{Kt} /$ year) represent cross-border local trade transactions and do not exceed $30 \mathrm{Kt}$ per year. A significant part of ferrosilicon produced in Russia is exported - 34-46\% of production, with an increase in the share of exports over time (see fig. $5 b$ ). The maximum export volume was $493 \mathrm{Kt}$ in 2015.

The dynamics of ferrosilicon world prices is characterized by: a stable level for the period 2001-2003; then price increases in 2004-2008; prices falling with a local minimum in 2009 and a relatively high level of prices in 2010-2015. Russian export prices are constantly 10-25\% lower than world prices (see fig. 2, FeSi).

Russian production of industrial silicon (Bratsk FAP JSC, Kremniy JSC and RUSAL Kremniy-Ural LLC) is at the level of 50-70 Kt/year, most of which 23-48 Kt/year is exported (2000-2015). Starting from 2016, the export flow of technical silicon has decreased to $15 \mathrm{Kt}$ in 2019

Silicocalcium along with ferrosilicon is produced in the process chain at Chelyabinsk IEMP PJSC. Its production 
and consumption was at the beginning of the XXI century at the level of 12-13 Kt/year, but since 2014 it has decreased to $0.7-1.0 \mathrm{Kt} /$ year owing to the low demand.

Low-tonnage ferroalloys include ferrovanadium, ferroniobium, ferronickel, ferromolybdenum, ferrotungsten and other ferroalloy compounds.

Ferrovanadium. Ferrovanadium flow dynamics in Russia is shown in fig. 2, FeV. Vanadium slags from the ores of the Gusevogorsk and Kachkanar titanomagnetite deposits in the Sverdlovsk Region are used as a source of raw materials. Ferrovanadium is produced at EVRAZ vanadium Tula JSC. The production of ferrovanadium in Russia is $10-14 \mathrm{Kt}$ per year, their volumes change over time in waves with peaks in 2004 and 2015 and minimums in 2002 and 2009. Import of ferrovanadium is sporadic and insignificant $(0.1-1.0 \mathrm{Kt} /$ year). Exports of ferrovanadium in 2000-2007 were 6-9 Kt year (52-72\% of production), mainly to the Netherlands and Ukraine (see fig. 4, FeV), but later decreased to $1-3 \mathrm{Kt} /$ year, amounting $1.3 \mathrm{Kt}$ (12\% of production) in 2019 , see fig. $5 b$. At the same time, the export flow of vanadium pentoxide (feedstock for the production of ferrovanadium and petrochemical catalysts) for the entire period of time (20002019) is significantly higher compared to ferrovanadium and is 3-9 Kt/year (8-18\% of production).

Dynamics of the prices for ferrovanadium includes an upward trend in the period between 2001and 2008, a fall in 2009, and stabilization in the period 2009-2016 and renewed growth in 2017-2018. It was the drop in prices in 2009 that led to a sharp decline in the export of Russian ferrovanadium.

The resource base of vanadium, on the one hand, is practically unlimited, because of its concentration in titanomagnetites, on the other hand, it is problematic due to the unattractiveness of the development of new titanomagnetite deposits. However, another source of vanadium is possible by extracting heavy oils from vanadium-bearing heavy oils of the Volga-Ural, TimanPechersk and Caspian provinces, as is done in Canada and Venezuela [22].

Ferroniobium. Small-scale production of niobium raw materials (loparite concentrate, up to $9 \mathrm{Kt} /$ year, equivalent to 300 tons of $\mathrm{Nb}_{2} \mathrm{O}_{5}$ per year) in Russia is at the Lovozerskoye field in the Murmansk Region. At present, niobium raw materials (pyrochlore and columbite concentrates) are practically absent in world trade, which is due to the monopoly supply of ferroniobium produced in Brazil.

The dynamics of ferroniobium fluxes in Russia is shown in fig. 2, FeNb. Extremely small volumes of ferroniobium production are at the Solikamsk magnesium plant PJSC Klyuchevsky FAP JSC, and almost all of its required volume is imported. There is a dynamic increase in Russian consumption of ferroniobium from 400 tons in 2000 to $5-6 \mathrm{Kt} / \mathrm{year}$ to date. Own production of ferroniobium is only up to $200 \mathrm{t} /$ year. Bulk of the imported ferroniobium (75-90\%) comes from Brazil - up to 6.6 $\mathrm{Kt}$ (see fig. 3, FeNb).
Ferroniobium prices are independent of the dynamics of economic factors affecting large-tonnage ferroalloys (see fig. 2, FeNb). Their significant growth was in 2007-2013 without failure in the crisis year of 2009, which was the case for most commodity commodities. Until 2012, the prices of ferroniobium imports to Russia were $20-40 \%$ lower than the world prices, and later on they were approximately equal to the world ones.

There are fairly well-known niobium deposits in Russia, including super-rich, such as Tomtorskoye in the Republic of Sakha (Yakutia) [23] and Chuktukonskoye in the Irkutsk Region [8], which are expected to commence operation. This can completely solve the problem of Russia's import dependence on niobium [24].

Ferromolybdenum. Ferromolybdenum flow dynamics in Russia is shown in fig. 2, FeMo. In the 90ies, the processing of molybdenite concentrate into ferromolybdenum was practically stopped, and Russian needs for it were satisfied by import [25]. Only because of the ferromolybdenum world prices growth, starting from 2004, its production resumed, including new specialized ferromolybdenum plants - Sorsky FMP LLC (2005), Zhirekenskiy FMP LLC (2006) and Nizhnevolzhskiy FAP LLC (2017). Ferromolybdenum production is currently also carried out at Kamyshin FFP JSC, Ryazan PFA \& L LLC and Moliren LLC. Raw materials for the production are molybdenite concentrates from the Sorskoye (Republic of Khakassia) and Mikheevskoye (Chelyabinsk Region) deposits (up to $10.3 \mathrm{Kt} /$ year) and imported from the Netherlands, the USA and Chile (up to $3.8 \mathrm{Kt} /$ year).

The production of ferromolybdenum in 2000-2002 in Russia was only 50-250 tons. These requirements were offset by imports in the amount of 2-3 Kt/year from various suppliers, mainly from China (see fig. 3, FeMo). After the expansion of ferromolybdenum production, the Russian supply increased by 2007 to $7 \mathrm{Kt}$ and remained at this level until now; since 2005, imports have practically stopped (see fig. $5 a$ ). Due to the excessive supply, most of the production of ferromolybdenum is exported - up to $8 \mathrm{Kt} /$ year (70-90\% of production, see fig. $5 b$ ), mainly to the Netherlands (see fig. 4, FeMo).

The dynamics of ferromolybdenum prices includes rapid growth since 2003 with two highs in 2005 and 2008, a dip in prices in 2009 as a result of the financial crisis and a slow decline in prices in the period 2010-2016. Export prices of Russian ferromolybdenum in 2007-2008 were disordered (sharply higher or lower than the world level), but since 2009 - approximately equal to the world level.

Small volumes (first hundreds of tons per year) of metal molybdenum are produced at the powder metallurgy plant of JSC Polema in Tula.

Ferrotungsten. The situation with the tungsten industry in Russia is very difficult - most of the produced tungsten concentrates (50-85\% of production) and ammonium paratungstate + tungsten anhydrite (50-90\%) are exported, while the same raw materials are imported $(1.1-1.7 \mathrm{Kt} /$ year of tungsten concentrate and up to $0.7 \mathrm{Kt} /$ year of ammonium paratungstate + tungsten an- 
hydrite) [26]. Tungsten raw materials (up to $7.3 \mathrm{Kt} / \mathrm{year}$ ) are mined at the Lermontovsky and Vostok-2 deposits in the Primorsky Kray, Burun-Narynsky in the Republic of Buryatia and Spokoininsky in the Zabaikalsky Kray. A significant part of the tungsten concentrate is processed at Hydrometallurg (Nalchik, Kabardino-Balkarian Republic) into tungsten anhydrite and ammonium paratungstate, at the Kirovograd non-ferrous alloy plant into tungsten carbide and metal tungsten - at the powder metallurgy plant of JSC Polema in Tula. Ferrotungsten is produced by Klyuchevskoy FFS, Ryazan FFS and Moliren in total up to $2.5 \mathrm{Kt} /$ year, most of it is exported (up to $2.3 \mathrm{Kt} /$ year).

The demand for tungsten products is determined by the supply in the Chinese market, which provides $85 \%$ of the world's tungsten products. Therefore, prices for ferrotungsten fluctuate within a very wide range from 15 to 35 US \$ $/ \mathrm{kg}$. As a result, the problematic Russian tungsten industry is unattractive for investors.

Ferrotitanium. There is practically no extraction of titanium raw materials in Russia, and ilmenite concentrate consumed for the production of titanium sponge, pigment titanium dioxide and ferrotitanium is mainly imported from Ukraine (up to $215 \mathrm{Kt} /$ year). The world production of ferrotitanium is limited due to the release of alternative products - spongy titanium [27]. Russian ferrotitanium production is $22-31 \mathrm{Kt} /$ year. Most of its production is running in parallel with the production of titanium sponge VMSPO-AVISMA and Solikamsk MP. Ferrotitanium production from titanium scrap and scrap processing is carried out by Kanta, Nova Met, Cascade Titan and Zubtsovsky MP. Most of ferrotitanium is exported (50-88\% of production), and the share of Russian exports in world trade is quite high (22-38 \%). Russian export prices for ferrotitanium are approximately equal to world prices.

Ferronickel. Ferronickel is produced by processing silicate (oxide) nickel ores and matte in the South Uralskiy NK, Svetlinskiy FNP, Special Ferroalloys LLC and Serovskiy FAP. The world production of ferronickel also tends to decrease due to the reduction of the raw material base [28]. The volume of its production in Russia was 20-40 Kt/year in 2000-2014. But at the end of the oxide ores extraction at the South Ural deposits of silicate nickel ores in the Orenburg region and the appearance of an export flow of nickel matte to Finland, the production of ferronickel began to decline up to $8 \mathrm{Kt}$ in 2019. The export of ferronickel amounted to $15-40 \mathrm{Kt} /$ year until 2014 (50-100\% of production) and by 2019 , decreased to $0.9 \mathrm{Kt}$.

Other ferroalloys (ferroboron, ferrocerium, ferrophosphorus, ferozirconium, ferrocobalt, etc.), and foundry alloys (magnesium-aluminum, copper-aluminum, aluminum-niobium, rare metal, rare earth and other multicomponent alloys) - more than 400 commercial products in total (produced in small volumes up to $1-1.5 \mathrm{Kt} /$ year) and their total production in Russia is up to $310 \mathrm{Kt} /$ year. The volumes of import and export flows are small and do not exceed a total of $15 \mathrm{Kt}$ /year in each direction.

\section{Import dependence and export orientation of Russian ferroalloys}

Import, export and flows of ferroalloys are very significant both in weight and in value (see Table 2 ).

In 2019, the total import flows of ferroalloys and raw materials in Russia are $362 \mathrm{Kt}$ (491 million USD) and 2.2 billion tons (696 million USD), and export flows $859 \mathrm{Kt}$ (1.3 billion USD) and $123 \mathrm{Kt}$ (US \$ 238 million), respectively.

Import flows. The most critical situation is the dependence on imports of manganese raw materials (100\% of consumption), especially against the background of an increase in Russian demand for manganese ferroalloys. Even the commissioning of the Usinsk deposit in the Kemerovo Region will cover only $15 \%$ of the Russian demand for manganese raw materials. Nevertheless, the increase in the national production of ferromanganese led to the elimination of its import dependence (from $66 \%$ in 2001 to $8 \%$ in 2019) and a decrease in the import dependence of silicomanganese (from $92 \%$ in 2005 to $36 \%$ in 2019), see fig. $5 a$. Simultaneously, the proportion of Russian imports of these goods in the volume of world trade falls: ferromanganese - from $12 \%$ to $3 \%$, silicomanganese - from $20 \%$ to $6 \%$ (see fig. 5 c). Manganese metal remains completely import-dependent (100\% of consumption), and the share of Russian imports of this product in the volume of world trade increases over time (from $3 \%$ to $11 \%$ ), see fig. $5 c$. Therefore, the project of ore redistribution from the Usinsk deposit to metallic manganese at Tuim NFMPP LLC is very relevant $[8,20]$.

An equally problematic situation of complete import dependence (up to $97 \%$ of consumption) remains for ferroniobium, but for this product it is possible to completely replace imports with the implementation of projects for the development of rich niobium deposits available in Russia [8,23,24]. Considering the rapid growth in time of ferroniobium consumption from 0.4 to $5.0 \mathrm{Kt} /$ year (see fig. 2, FeNb), and the increase of the proportion of Russian imports in the volume of world trade of this product - from $1.5 \%$ to $5 \%$ (see fig. $5 c$ ) investment performance in these projects can be high.

The problem of import dependence on ferromolybdenum was eliminated precisely because of the implementation of projects for the construction of new ferromolybdenum plants. This problem decreased from $100 \%$ in 2000-2001up to $0.5 \%$ in 2005 (see fig. 5a). At the same time, the volume of imports of molybdenite concentrates, which amounted to 2000-2007. 0.3-2.3 Kt/year (100\% of consumption) not only remained, but even increased in 2014-2019 to $2.8-8.6 \mathrm{Kt} /$ year (24-59 \% of consumption). This ensures the loading of ferromolybdenum plants with the formation of a technological transit flow: import of raw materials $\rightarrow$ processing of imported and national concentrates into ferromolybdenum $\rightarrow$ export of commercial ferromolybdenum.

There remain large import-dependent raw material flows: chromite ores and concentrates (805-1190 Kt/year, 


\begin{tabular}{|c|c|c|c|c|c|c|}
\hline & \multicolumn{4}{|c|}{ Mass th. tonnes } & \multicolumn{2}{|c|}{ Value US \$ million } \\
\hline & production & import & export & net consumption & import & export \\
\hline \multicolumn{7}{|c|}{ Raw materials for ferroalloy production } \\
\hline Manganese ore & 0,0 & 1081,2 & 16,7 & 1064,5 & 246,8 & 4,8 \\
\hline Chromium ore & 510,0 & 903,0 & 14,3 & 1398,7 & 153,1 & 3,1 \\
\hline Vanadic pentoxide & 58,2 & 3,5 & 9,7 & 52,0 & 121,7 & 177,8 \\
\hline Molybdenum ore & 5,5 & 3,8 & 0,1 & 9,2 & 49,0 & 1,0 \\
\hline Tungsten ore & - & 0,3 & 2,6 & 3,2 & 3,4 & 24,5 \\
\hline $\begin{array}{l}\text { Ammonium paratungstate }+ \\
\text { tungsten anhydrite }\end{array}$ & 2,5 & 0,3 & 0,3 & 2,5 & 6,4 & 7,0 \\
\hline Titanic ore (ilmenite concentrate) & 0,0 & 304,5 & 0,7 & 303,8 & 115,1 & 0,4 \\
\hline Nickel ore and matte & No data & 0,0 & 78,4 & No data & 0,0 & 19,7 \\
\hline Raw materials total & - & 2296,6 & 122,8 & - & 695,5 & 238,3 \\
\hline \multicolumn{7}{|c|}{ Ferroalloys } \\
\hline Ferromanganese & 273,4 & 18,1 & 78,1 & 213,4 & 77,3 & 2,5 \\
\hline Silicomanganese & 377,3 & 179,4 & 52,1 & 504,6 & 53,0 & 19,1 \\
\hline Metal manganese & 0,0 & 60,1 & 0,1 & 60,0 & 126,3 & 0,3 \\
\hline Ferrochrome & 463,2 & 37,2 & 267,7 & 232,7 & 4,7 & 465,1 \\
\hline Metallic chromium & 19,5 & 0,1 & 19,2 & 0,4 & 0,7 & 139,1 \\
\hline Ferrosilicon & 864,6 & 40,3 & 380,5 & 524,4 & 4,3 & 458,8 \\
\hline Industrial silicon & 60,0 & 10,0 & 15,6 & 54,4 & 26,9 & 26,2 \\
\hline Ferrovanadium & 10,9 & 0,1 & 1,3 & 9,7 & 2,5 & 31,4 \\
\hline Ferroniobium & 0,2 & 4,8 & 0,05 & 5,0 & 100,7 & 1,1 \\
\hline Ferromolybdenum & 3,0 & 0,2 & 2,2 & 1,0 & 3,4 & 39,7 \\
\hline Ferrotungsten & 2,0 & 0,01 & 1,3 & 0,7 & 0,2 & 28,8 \\
\hline Ferrotitanium & 25,0 & 0,1 & 22,1 & 3,0 & 0,2 & 47,5 \\
\hline Ferronickel & 8,0 & 0,1 & 7,1 & 1,0 & 0,3 & 4,0 \\
\hline Other ferroalloys and alloyages & 310,0 & 11,4 & 11,3 & 310,1 & 18,5 & 23,1 \\
\hline Ferroalloys total & 2417,1 & 361,9 & 858,6 & 1920,4 & 419,0 & 1286,7 \\
\hline
\end{tabular}

$57-72 \%$ of consumption) and ilmenite concentrate (101-305 Kt/year, 100\% of consumption). However, they are not critical for the production of chromium and titanium ferroalloys. The production volumes of ferrochrome from Russian raw materials exceed its required national consumption, and the existing technological transit flow of ferrochrome production from imported raw materials is a sustainable commercial solution. The total import dependence of titanium raw materials is a risk factor for the production of titanium sponge and pigment titanium dioxide, but not for ferrotitanium, the production volumes of which are small, and in addition, it can be produced during the redistribution of titanium scrap.

Export flows. The largest export flow of ferrosilicon has no problems with the raw materials base and production capacities, it increases over time from $237 \mathrm{Kt}$ in 2000 to $493 \mathrm{Kt}$ in 2015, with an increase in the share of exports (from production) over this period from $34 \%$ to $46 \%$ (see fig. $5 b$ ). At the same time, the share of Russian exports of ferrosilicon in the volume of world trade is growing from 13 to $21 \%$ (see fig. $5 d$ ). Russia has a good position in the world ferrosilicon market, but there is also a negative factor in the remoteness of its main producers from seaports of transshipment and delivery to consumers [29].

The export flow of ferrochrome, the second in terms of sales of Russian ferroalloys, is a purely commercial de- cision due to the high prices for this marketable product. Therefore, a technological transit flow of ferrochrome production from imported raw materials is used, and the export volumes correlate with the level of world prices for it, increasing to 350-415 Kt/year in 2005-2014 and decreasing to 215-265 Kt/year in 2015-2019. The share of Russian exports of ferrochromium in world trade is variable, increasing from $2.3 \%$ in 2001 to $7.9 \%$ in 2009 and decreasing to $2.9 \%$ by 2019 (see fig. $5 d$ ). For the export of ferrochrome, there is also the problem of the remoteness of its main producers from seaports of transshipment [23].

Ferrovanadium is one of the most expensive ferroalloys (US \$ 20-50/kg) and for export in 2000-2007 sent $5.9-8.7 \mathrm{Kt} /$ year $(50-70 \%$ of its production). But an increase in the national consumption of ferrovanadium and a sharp increase in the production of this commercial product in China led to a decrease in the export flow to $0.7 \mathrm{Kt}$ in 2018 ( $6 \%$ of production).

Ferromolybdenum, being in 2000-2005 import-dependent product, in connection with the commissioning of new ferromolybdenum plants, has become a completely export-oriented product, with deliveries in 2007-2016 for export 5.0-8.2 Kt/year (68-100\% of production). The decline in exports to $1.7 \mathrm{Kt}$ in 2017 is temporary, because with a decline in the production of Russian molybdenum ores, the volume of imports of molybdenite concentrate increases significantly. 


\section{Russian ferroalloys in world production and consumption}

World production. The dynamics of the shares of the Russian supply of certain ferroalloys in the volume of their world production are shown in fig. 5e. They reflect changes in Russian production volumes against the background of actions of other countries: producers, sometimes monopoly (Brazil for ferroniobium, South Africa and China for ferrovanadium, China for ferromolybdenum, etc.) and consumers (steel production in China).

The share of Russian ferrovanadium in world production is the highest, but it tends to decrease from $23 \%$ in 2004 to $14 \%$ in 2018 (see fig. 5e). This is due to higher levels of ferrovanadium production in South Africa (up to $20 \mathrm{Kt} /$ year), and since 2012 in China (up to $30 \mathrm{Kt} /$ year).

The largest in terms of production (and export) flow of ferrosilicon also tends to decrease its share in world production - from $13 \%$ in 2000 to $8 \%$ in 2017.

The only major increase in the share in world production is in Russian ferromolybdenum, which increased from $0 \%$ in 2000 to $7.5 \%$ in 2008 , but later the share of global production began to decline due to a sharp increase in ferromolybdenum production in China.

World consumption. The dynamics of the shares of Russian demand ferroalloys in the volume of their world consumption in steel production are shown in fig. $5 f$.

There is an increase in the share of Russian consumption in world demand for ferrovanadium, ferroniobium and metal manganese (with a peak of maximum consumption in 2015), a decrease in the share of demand for ferrosilicon, silicomanganese, and ferromolybdenum. The national consumption of ferrochrome is approximately at the same level, and that of ferromanganese is variable over time.

The most significant growth in the share of national demand in the volume of world consumption is observed for ferrovanadium - from $6.4 \%$ in 2001 to $16.8 \%$ in 2015. A similarly significant growth in the share of national consumption in world volumes is observed for ferroniobium - from $1.3 \%$ in 2000 to $7.8 \%$ in 2015. For manganese metal, the growth in the share of consumption is also significant - from $1.6 \%$ in 2000 to $4.2 \%$ in 2015 .

The decline in the share of national consumption of ferrosilicon in its world volumes - from $9.9 \%$ in 2001 to $4.6 \%$ in 2018 , silicomanganese - from $7.7 \%$ in 2000 to $3.0 \%$ in 2018 .

Varying dynamics of changes in consumption shares takes place:

for ferromanganese - a decrease from $6.9 \%$ in 2000 to $2.6 \%$ in 2012 and subsequent growth to $4.5 \%$ in 2017 ;

for ferromolybdenum - a decrease from $11.3 \%$ in 2000 to $1.3 \%$ by 2012 and fluctuations in the share of consumption from 1.5 to 3.0 in the subsequent period.

\section{Conclusions}

Ferroalloys and raw materials for them are strategically important commodity products that ensure the stability of the ferrous metallurgy. The presence of a significant dependence on imports of certain ferroalloys and raw materials for their production increases the risks of the stability of the entire industry of the national economy.

Among the ferroalloys, there are groups: importdependent (manganese ores, metallic manganese, silicomanganese, chromium ores, ferroniobium), exportoriented (ferrosilicon, ferrochrome, metallic chromium, ferrovanadium, ferromolybdenum) and counter importexport flows (ferromanganese).

Solving the problem of import substitution of problematic ferroalloys and their raw materials is possible by introducing new deposits of scarce raw materials (manganese, chromium, niobium) into the development, stabilizing import flows from friendly SCO and BRICS countries, creating new ferroalloy production facilities, introducing new technologies for processing raw materials, as well as waste from ferroalloy plants, changes in the structure of consumption of ferroalloys in metallurgy.

During the study period, ferromolybdenum and ferromanganese ceased to be import-dependent goods, and import dependence on silicomanganese has significantly decreased.

The share of Russia in the world production of ferromolybdenum increased (up to 5-8\%), while ferrovanadium and ferrosilicon decreased. The share of Russian consumption (in the volume of world demand) of ferrovanadium (up to $11-17 \%$ ) and ferroniobium (up to 5-7\%) has grown, the share of national demand for ferrosilicon and silicomanganese in the volume of world supply is falling.

The proportion of Russian imports in the volume of world trade increased for metallic manganese (up to $11-16 \%$ ) and for ferroniobium (up to 5-7\%), the share of national imports of silicomanganese and ferromanganese decreased. The share of Russian exports in the volume of world trade increased for ferrosilicon (up to $17-21 \%$ ) and for ferromolybdenum (up to 5-7\%), while the share of national exports of ferrovanadium decreased.

This research was supported by TPU development program.

\section{REFERENCES}

1. Leontyev L. I., Zhuchkov V. I., Zhdanov A. V., Dashevskii V. Y. Ferroalloy production in Russia. Steel in Translation. 2015. Vol. 45 No. 10. pp. 773-777. DOI: 10.3103/S0967091215100101.

2. Leontyev L. I., Smirnov L. A., Zhuchkov V. I., Zhdanov A. V., Dashevskii V. Y., Gurova S. A. Status and prospects of ferroalloys production in the Russian Federation. Metallurgist. 2016. Vol. 59. No. 11-12. pp. 1001-1006. DOI: 10.1007/s11015016-0206-x.

3. Lapteva A. M., Mitrofanov N. P., Tigunov L. P. Alloying metal supply: State-of-the art, problems and prospects. Gornyi zhurnal. 2017. No. 7, pp. 10-16. DOI: 10.17580/gzh.2017.07.02.

4. Zhuchkov V. I., Leontyev L. I., Zayakin O. V. Ferroalloy production using Russian crude ore. Steel in Translation. 2020. Vol. 50. No. 4. pp. 223-228. DOI: 10.3103/ S0967091220040129.

5. Khatkov V. Yu., Boyarko G. Yu. Import regulation for mineral raw materials that are lacking in Russia. Gornyi zhurnal. 2005. No. 9-10. pp. 53-56.

6. Petrov I. M., Posysoyeva D. S. Russia on the market of metal mineral raw materials and products of its enrichment in the CIS countries. Mineralnye resursy Rossii. Ekonomika i upravlenie. 2007. No. 6. pp. 65-69. 
7. Petrov I. M. Russia on the world market of metallic mineral raw materials. Mineralnye resursy Rossii. Ekonomika i upravlenie. 2011. No. 3. pp. 85-89.

8. State report «State and use of mineral resources of the Russian Federation in 2017-2018». Available at: http://www.mnr.gov. ru/docs/o_sostoyanii_i_ispolzovanii_mineralno_syrevykh_ resursov rossiyskoy federatsii/gosudarstvennyy doklad o sostoyanii_i_ispolzovanii_mineralno_syrevykh_resursov_ rossiyskoy federatsii/. (accessed: 01 November 2020).

9. Federal state statistics service of Russia. Available at: http://www. gks.ru/. (accessed: 01 November 2020).

10. Federal customs service of Russia. Available at: http://stat.customs.gov.ru/analysis (accessed: 01 June 2021)

11. UnData. A world of information. Available at: https://data. un.org/ (accessed: 01 November 2020).

12. TrendEconomy. Global database of foreign trade. Available at: dataexplorer (trendeconomy.ru) (accessed: 01 June 2021).

13. Information and analytical center «Mineral». Available at: http://www.mineral.ru/Center/index.html (accessed: 01 November 2020)

14. Boyarko G. Yu., Khatkov V. Yu. Critical commodity flows of manganese raw materials in Russia. Izvestiya Tomskogo Politekhnicheskogo Universiteta. Inzhiniring georesursov. 2020. Vol. 331. No. 4. pp. 38-53. DOI: 10.18799/24131830/202 $0 / 4 / 2592$

15. Zhuchkov V. I., Zayakin O. V., Zhdanov A. V. Utilization of substandard and off grade raw materials for chromium and manganese ferroalloys production. Proceedings of the 12th International Ferroalloys Congress: Sustainable Future. INFACON 2010, Helsinki; Finland. 2010. pp. 311-315.

16. Leontyev L. I., Dashevskiy V. Ya., Kostina M. V., Zhuchkov V. I. Import substitution opportunities in the mining and metallurgical complex. Tyazheloe mashinostroenie. 2017. No. 1-2. pp. 19-24.

17. Khodina M. A. Russian market of manganese products and potential opportunities for its import substitution. Razvedka $i$ okhrana nedr. 2017. No. 2. pp. 42-48.

18. Dashevskiy V. Ya., Yusfin Yu. S., Aleksandrov A. A., Leontyev L. I., Podgorodetskiy G. S., Gubanov V. I. Increasing the useful use of manganese in the production of manganese ferroalloys. Izvestiya vuzov. Chernaya metallurgiya. 2013. No. 7. pp. 32-37. DOI: 10.3103/S0967091213070036.

19. Makeev D. B., Kozlova O. N., Polulyakh L. A., Petelin A. L., Aleksandrov A. A., Dashevskii V. Y. Involvement of the
Domestic Manganese Ores in Production. Metally (Russian Metallurgy). 2020. No. 9. pp. 938-941. DOI: 10.1134/ S0036029520090098.

20. Dashevskiy V. Ya., Yusfin Yu. S., Podgorodetskiy G. S., Baeva N. V. Production of manganese ferroalloys from manganese ores of the Usinsk deposit. Izvestiya vuzov. Chernaya metallurgiya. 2013. No. 9. pp. DOI: 10.3103/S0967091213090052.

21. Monsen B., Kolbeinsen L., Prytz S., Myrvågnes V., Tang K. Possible use of natural gas for silicon or ferrosilicon production. Proceedings of INFACON XIII - 13th International Ferroalloys Congress: Efficient Technologies in Ferroalloy Industry. Almaty; Kazakhstan; 2013. Code 160083. 2020. pp. 467-478.

22. Sukhanov A. A., Yakutseni V. P., Petrova Yu. E. Assessment of prospects for industrial development of the metal-bearing potential of oil and possible ways to implement it. Neftegazovaya geologiya. Teoriya i praktika. 2012. Vol. 7. No. 4. p. 15.

23. Tolstov A. V., Pokhilenko N. P. Samsonov N. Yu. New opportunities for obtaining rare earth elements from a single Arctic raw material source. Zhurnal Sibirskogo federalnogo universiteta. Seriya "Khimiya". 2017. Vol. 10. No. 1. pp. 125-138.

24. Boyarko G. Yu. Dynamics of global production and commodity flows of niobium raw materials. Izvestiya Tomskogo Politekhnicheskogo Universiteta. Inzhiniring georesursov. 2019. Vol. 330. No. 10. pp. 216-229. DOI: 10.18799/24131830/2 019/10/2318.

25. Elsukova M. A. Molybdenum market in the World and Russia. Mineralnye resursy Rossii. Ekonomika i upravlenie. 2014. No. 4. pp. 64-71.

26. Khatkov V. Yu., Boyarko G. Yu. Current state of tungsten industry in Russia. Izvestiya Tomskogo Politekhnicheskogo Universiteta. Inzhiniring georesursov. 2019. Vol. 330. No. 2. pp. 124137. DOI: $10.18799 / 24131830 / 2019 / 2 / 114$.

27. Gasik M. Technology of titanium ferroalloys. Handbook of ferroalloys. Butterworth-Heinemann is an Imprint of Elsevier. 2013. pp. 377-385. DOI: 10.1016/B978-0-08-0977539.00015-0.

28. Polyakov O. Technology of ferronickel. Handbook of ferroalloys. Butterworth-Heinemann is an Imprint of Elsevier. 2013. pp. 367-375. DOI: 10.1016/B978-0-08-097753-9.00010-1.

29. Gagarskiy E. A., Kozlov S. G., Kirichenko I. S. Tendencies of the Russian exports of ferroalloys and problems of containerization of freight traffic. Bulleten Transportnoy Informatsii. 2018. No. 2 (272). pp. $18-23$.

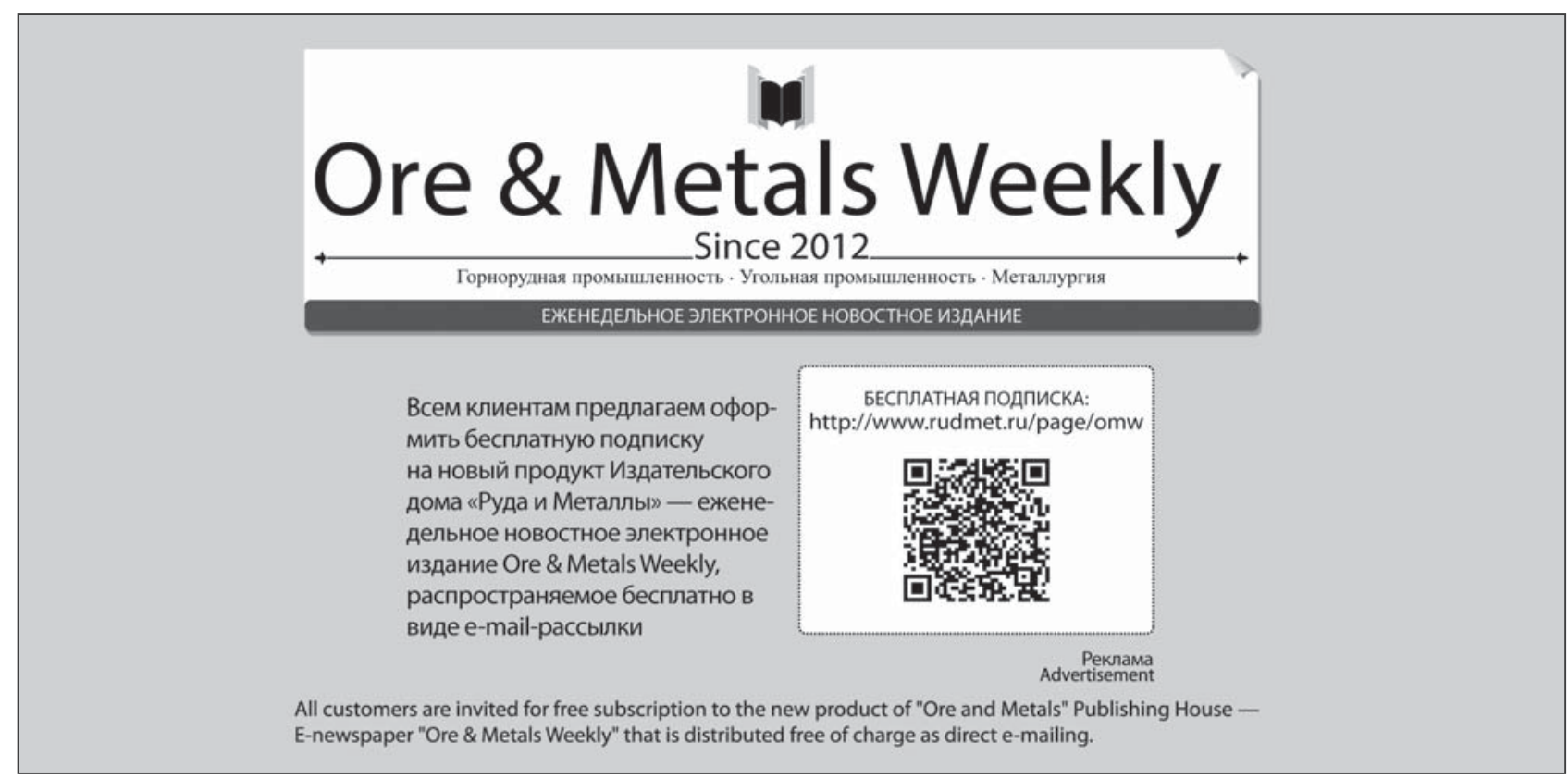

